\title{
Penerapan Pembelajaran Kontekstual Dengan Metode Inkuiri Untuk Meningkatkan Motivasi Dan Hasil Belajar
}

\author{
Santje Kaunang \\ Guru SMK Negeri 1 Airmadidi Minahasa Utara \\ santjekaunang@gmail.com
}

\begin{abstract}
ABSTRAK
Penelitian ini dilaksanakan pada siswa Kelas X Akuntansi SMK Negeri 1 Airmadidi yang terbagi menjadi dua siklus, di mana pada setiap siklus terdiri atas tahap perencanaan, pelaksanaan (tindakan), observasi, dan refleksi. Pengambilan data dilakukan dengan menggunakan tes, angket, observasi dan dokumentasi. Analisis data dilakukan dengan analisis kuantitatif maupun kualitatif. Penerapan model pembelajaran inkuiri melalui pendekatan kontekstual (Contextual Teaching Learning) dapat meningkatkan motivasi belajar siswa Kelas X Akuntansi SMK Negeri 1 Airmadidi. Aspek motivasi meliputi perhatian, keterkaitan, keyakinan/kepercayaan diri, dan kepuasan mengalami peningkatan antara 3,54\% hingga 11,41\%. Sedangkan peningkatan tertinggi dari aspek keyakinan/kepercayaan diri siswa yaitu sebesar 11,41\%.

Penerapan model pembelajaran inkuiri melalui pendekatan kontekstual (Contextual Teaching Learning) dapat meningkatkan hasil belajar siswa Kelas X Akuntansi SMK Negeri 1 Airmadidi yang meliputi ranah kognitif, afektif dan psikomotor. Siswa mengalami peningkatan pada ranah kognitif sebesar 10,27\% yaitu dari 78,57\% menjadi 89,29\%. Hasil belajar ranah afektif mengalami peningkatan antara 7,89\% hingga 10,53\%. Peningkatan yang paling tinggi yaitu pada aspek kognisi atau keyakinan siswa sebesar 10,53\%. Sedangkan peningkatan ranah psikomotor antara 27,27\% hingga 40,91\%. Peningkatan tertinggi diperoleh dari aspek kerelevanan dalam keterampilan menjelaskan yaitu sebesar 40,91\%. Nilai rata-rata kelas juga mengalami peningkatan sebesar 34,09\%. Pada ranah psikomotor yang diukur melalui kegiatan presentasi dan diskusi ini menunjukkan keterampilan pada hierarkhis yang paling tinggi tingkat naturalisasi, siswa melakukan gerakan tertentu secara spontan atau otomatis dalam mengajukan pertanyaan, menanggapi pertanyaan dan menjelaskan.
\end{abstract}

Kata Kunci : Motivasi dan hasil belajar Prakarya dan Kewirausahaan, model pembelajaran Inquiri, Pendekatan Kontekstual.

\section{PENDAHULUAN}

Berdasarkan hasil pengamatan yang dilakukan penulis sebagai guru mata pelajaran Prakarya dan Kewirausahaan di Kelas X Akuntansi SMK Negeri 1 Airmadidi menunjukkan bahwa masih menggunakan model pembelajaran konvensional. dengan pembelajaran di kelas didominasi oleh paham strukturalisme/ objektivisme/ behaviorisme yang bertujuan siswa mengingat informasi yang faktual. Pembelajaran dengan model diskusi juga dilakukan, tetapi sekitar 50\% yang mendapatkan respon dari siswa. Sedangkan siswa memahami materi pelajaran yang dipelajari $\leq 60 \%$ saja, hal ini dapat dibuktikan dari hasil ulangan harian Prakarya dan Kewirausahaan siswa hanya mencapai rata-rata 60,05 . 
Dari segi motivasi terhadap pembelajaran, siswa tidak antusias dengan model pembelajaran yang dilakukan saat ini, dikarenakan jarang memberikan semangat dan motivasi kepada siswa saat kegiatan pembelajarn berlangsung. Pelaksanaan pembelajaran sebatas penguatan kepada siswa yang dianggap pintar atau memiliki nilai akademik baik di kelas dan memarahi siswa yang tidak aktif. Suasana kelas menjadi menegangkan sehingga siswa takut untuk mengemukakan pendapat. Pembuktian saat kegiatan presentasi di kelas kurang lebih hanya 30\% siswa yang bersedia mengemukakan pendapat. Sementara hasil belajar siswa menjadi kurang maksimal akibatnya hasil belajar siswa banyak yang tidak tuntas pada setiap ulangan harian yaitu sekitar $70 \%$ siswa yang tidak tuntas belajar.

Berdasarkan pertimbangan tersebut maka model pembelajarn inkuiri melalui pendekatan kontekstual, cocok untuk diterapkan dalam mengaitkan materi yang diajarkan dengan situasi dunia nyata siswa dan mendorong siswa membuat hubungan antara pengetahuan yang dimiliki untuk diterapkan dalam kehidupan siswa sebagai anggota keluarga dan masyarakat. Dalam inkuiri, siswa dibimbing untuk menemukan konsep sendiri melalui pertanyaan atau berdasarkan masalah yang diajukan oleh siswa. Pembelajaran dikelola dalam bentuk kelompok-kelompok kecil yang merupakan kegiatan cooperating. Selama proses pembelajarn siswa didorong untuk merefleksi kemajuan belajar, melalui penilaian terhadap penampilan dari perolehan belajar siswa sendiri (authentic assesment). Siswa diajak menemukan sendiri fenomena-fenomena alam untuk menggali pengetahuan sehingga siswa dapat termotivasi dalam meningkatkan hasil belajar.

\section{LANDASAN TEORI}

\section{Model Pembelajaran Inkuiri}

Pembelajaran dengan penemuan atau inkuiri merupakan suatu komponen penting dalam pendekatan kontekstual. Dalam pembelajaran dengan inkuiri, siswa didorong untuk belajar sebagian besar melalui keterlibatan aktif siswa sendiri dengan konsepkonsep, dan guru mendorong siswa untuk memiliki pengalaman dan melakukan percobaan yang memungkinkan siswa menemukan konsep-konsep untuk diri siswa sendiri. Belajar dengan penemuan mempunyai beberapa keuntungan. Inkuiri adalah seni dan ilmu bertanya serta menjawab. Inkuiri melibatkan observasi dan pengukuran, pembuatan hipotesis dan interpretasi, pembentukan model dan pengujian model. Inkuiri menuntut ada eksperimentasi, refleksi, dan pengenalan akan keunggulan dan kelemahan metode-metodenya sendiri. Selama proses inkuiri, seorang guru dapat mengajukan suatu pertanyaan atau mendorong siswa untuk mengajukan pertanyaan-pertanyaan. Pertanyaan bersifat open-ended, memberi kesempatan kepada siswa untuk menyelidiki dan mencari jawaban sendiri (Nurhadi, 2004).

Siswa harus mengajukan pertanyaan-pertanyaan yang berarti dan berhubungan, melaporkan hasil temuan secara lisan maupun tertulis. Ketika guru menggunakan teknik inkuiri, guru tidak boleh banyak bertanya, dan terlalu banyak menjawab sebab akan mengurangi proses belajar siswa melalui inkuiri dan proses belajar tidak lagi menyenangkan. Siklus inkuiri terdiri atas: (1) Observasi (Observation); (2) Bertanya (Questioning); (3) Mengajukan dugaan (Hipotesis); (4) Pengumpulan data (Data gathering); (5) Penyimpulan (Conclusion) (Nurhadi, 2004).

Menurut Mbulu (2001) bahwa inkuiri atau penemuan adalah cara penyajian bahan pelajaran yang banyak melibatkan siswa dalam proses mental dalam rangka penemuan. Menurut Topati (1995 dalam Mbulu, 2004) inkuiri dikembangkan untuk mengajar siswa 
memahami proses meneliti, dan menerangkan kejadian. Tujuan akhir inkuiri atau penemuan adalah pembentukan pengetahuan baru.

\section{Pembelajaran Kontekstual}

\section{a. Pengertian Pendekatan Kontekstual}

Pembelajaran kontekstual adalah konsep dasar yang membantu guru mengaitkan antara materi yang diajarkan dengan situasi dunia nyata siswa dan mendorong siswa membuat hubungan antara pengetahuan yang dimiliki dengan penerapan dalam kehidupan mereka sehari-hari sebagai anggota keluarga dan masyarakat, dengan melibatkan tujuh komponen utama pembelajaran efektif yaitu konstruktif, bertanya, menemukan, masyarakat belajar, pemodelan, refleksi dan penilaian sebenarnya (Nurhadi, 2002:3).

Menurut Sanjaya (2005:109) Contextual Teaching Learning (CTL) adalah suatu pendekatan pembelajaran yang menekankan kepada proses keterlibatan siswa secara penuh untuk dapat menemukan materi yang dipelajari dan menghubungkan dengan situasi kehidupan nyata sehingga mendorong siswa untuk dapat menerapkan dalam kehidupan. Sedangkan Nurhadi (2004:13) merumuskan pengertian pembelajaran kontekstual atau Contextual Teaching Learning sebagai konsep belajar dengan guru menghadirkan dunia nyata ke dalam kelas dan mendorong siwa membuat hubungan antara pengetahuan yang dimiliki dengan penerapan dalam kehidupan sehari-hari, sementara siswa memperoleh pengetahuan dan ketrampilan dari konteks yang terbatas, sedikit-demi sedikit, dan dari proses mengkontruksi sendiri, sebagai bekal untuk memecahkan masalah dalam kehidupannya sebagai anggota masyarakat.

Menurut Johnson \& Johnson (dalam Nurhadi 2004:13) karakteristik pembelajaran kontekstual (Contextual Teaching Learning) ada delapan komponen utama yaitu (1) melakukan hubungan yang bermakna (making meaningful connections); (2) melakukan kegiatan yang signifikan (doing significant work); (3) belajar yang diatur sendiri (selfregulated learning); (4) bekerjasama (collaborating); (5) berpikir kritis dan kreatif (critical and creative thinking); (6) mengasuh atau memelihara pribadi sendiri (nurthuring the individual); (7) mencapai standar yang tinggi (reaching high standards); (8) menggunakan penilaian authentik (using authentic assessment).

Sedangkan The Northwest Regional Education laboratory USA dalam (Nurhadi, 2004:14) mengidentifikasikan ada 6 kunci dasar pembelajaran kontekstual yaitu :

1. Pembelajaran bermakna

2. Penerapan pengetahuan

3. Berpikir tingkat tinggi

4. Kurikulum yang dikembangkan berdasarkan standar

5. Responsif terhadap budaya

1. Penilaian authentik

\section{b. Komponen Pendekatan Kontekstual (Contextual Teaching Learning)}

Pembelajaran kontekstual mempunyai tujuh komponen utama. Menurut Nurhadi (2002:9) komponen-komponen pembelajaran kontekstual yaitu sebagai berikut: (1) konstruktivis (constructivism), (2) menemukan (inquiry), (3) bertanya (questioning), (4) masyarakat belajar (learning community), (5) permodelan (modeling), (6) refleksi (reflection), (7) penilaian sebenarnya (authentic assessment).

Konstruktivis merupakan landasan berpikir pembelajaran kontekstual maksudnya bahwa pengetahuan dibangun oleh manusia sedikit demi sedikit yang 
hasilnya diperluas melalui konteks yang terbatas. Pengetahuan bukanlah seperangkat fakta-fakta konsep, atau kaidah yang siap untuk diambil dan diingat. Manusia harus mengkonstruksikan pengetahuan itu melalui pengalaman nyata.

Komponen berikutnya adalah permodelan yaitu sebuah pembelajaran ketrampilan atau pengetahuan tertentu ada model yang dapat ditiru. Model bisa berupa cara mengoperasikan sesuatu. Komponen refleksi juga tidak kalah penting dalam pembelajaran kontekstual. Menurut Nurhadi (2002:15) refleksi adalah cara berpikir tentang apa yang baru dipelajari atau berpikir ke belakang tentang apa yang sudah dilakukan di masa lalu. Refleksi merupakan respon terhadap kejadian aktivitas atau pengetahuan yang baru diterima.

\section{c. Keunggulan Kontekstual (CTL)}

Pendekatan yang tepat dalam pembelajaran sangat menentukan keberhasilan pendidikan. Menurut Nurhadi (2004:4), alasan pengembangan pembelajaran kontekstual (CTL) yaitu : (a) adanya pandangan bahwa pengetahuan merupakan fakta yang harus dihafal, (b) adanya landasan filosofi konstruktivis, (c) pengetahuan dan ketrampilan harus ditemukan sendiri oleh siswa, dan (d) pengetahuan adalah pengetahuan yang dapat diterapkan.

"Konteks-konteks apakah yang tepat untuk dicari oleh manusia?" dan "Langkahlangkah kreatif apakah yang harus saya ambil untuk membentuk dan memberi makna pada konteks?" (Alwasilah, 2007).

Siswa aktif terlibat dalam proses pembelajaran dan pembelajaran tersebut dikaitkan dengan kehidupan sehari-hari siswa baik di lingkungan sekolah, keluarga maupun masyarakat (Alwasilah, 2007).

Kontekstual menempatkan siswa sebagai subyek yaitu siswa berperan aktif dalam setiap proses pembelajaran dengan cara menemukan dan menggali sendiri materi pelajaran. Dalam pembelajaran kontekstual, siswa belajar melalui kegiatan kelompok, berdiskusi, saling menerima, dan memberi yang pembelajarannya dikaitkan dengan kehidupan nyata secara riil. Kemampuan dalam pembelajaran ini didasarkan atas pengalaman.

Tujuan yang ingin dicapai dalam Kontekstual (CTL) adalah seluruh aspek perkembangan siswa, sehingga keberhasilan pembelajaran diukur dengan berbagai cara antara lain melalui tes, hasil karya siswa, observasi, rekaman, wawancara dsb.

\section{d. Motivasi}

\section{Pengertian Motivasi}

Salah satu karakteristik siswa yang paling penting bagi keberhasilan belajar siswa adalah motivasi. Motivasi sering dikatakan sebagai dorongan dari dalam maupun luar diri seseorang untuk melakukan sesuatu. Motivasi belajar merupakan sesuatu yang menimbulkan, mengarahkan, mendorong kita untuk melakukan kegiatan belajar. Winkel (1997:92) menyatakan motivasi belajar adalah keseluruhan daya penggerak psikis di dalam diri siswa yang menimbulkan kegiatan belajar. Sehingga motivasi belajar siswa merupakan keseluruhan daya penggerak psikis di dalam diri siswa yang menimbulkan kegiatan belajar, menjamin kelangsungan kegiatan belajar dan memberikan arah pada kegiatan belajar demi mencapai suatu tujuan (Dimyati, 1998). Menurut Louisell dan Descamps (dalam Susanto, 1999) motivasi belajar merupakan hal yang amat penting bagi kelangsungan belajar dan peningkatan prestasi belajar. Guru mungkin sangat menguasai bahan pelajaran dan teknik pembelajaran, tetapi jika mereka tidak tahu bagaimanan cara 
meningkatkan keterlibatan siswa dalam belajar, maka usaha-usaha yang mereka lakukan akan sia-sia.

Dalam motivasi terkandung adanya keinginan, harapan, kebutuhan, tujuan dan sasaran. Keadaan jiwa inilah yang mengaktifkan, menggerakkan, menyalurkan dan mengarahkan sikap dan perilaku individu belajar (Koeswara,1989).

Terdapat tiga komponen utama dalam motivasi yaitu: 1) kebutuhan, 2) dorongan, 3) tujuan. Dorongan yang berorientasi tujuan tersebut merupakan inti motivasi sedangkan tujuan adalah hal yang ingin dicapai oleh seseorang individu. Tujuan tersebut mengarahkan perilaku dalam hal ini perilaku belajar (Koeswara,1989).

\section{Pentingnya Motivasi Dalam Belajar}

Perilaku yang penting bagi manusia adalah belajar dan bekerja. Belajar menimbulkan perubahan mental pada diri siswa. Bekerja menghasilkan sesuatu yang bermanfaat bagi perilaku dan orang lain. Motivasi belajar dan motivasi bekerja merupakan penggerak kemajuan masyarakat. Kedua motivasi tersebut perlu dimiliki oleh siswa SMK.

Motivasi belajar pada siswa bermanfaat bagi guru, sebagai berikut a) Membangkitkan, meningkatkan dan memelihara semangat siswa untuk belajar sampai berhasil membangkitkan, bila siswa tak bersemangat; meningkatkan, bila semangat belajarnya timbul tenggelam; memelihara, bila semangatnya telah kuat untuk mencapai tujuan belajar. Dalam hal ini, hadiah, pujian, dorongan atau pemicu semangat belajar b) Motivasi belajar siswa di kelas bermacam-macam; ada yang acuh tak acuh, ada yang tak memusatkan perhatian, ada yang bermain di samping yang bersemangat untuk belajar, ada yang berhasil dan ada yang tidak berhasil. Dengan bermacam-macam motivasi belajar tersebut maka guru dapat menggunakan bermacam-macam strategi dalam mengajar c) Meningkatkan dan menyadarkan guru untuk memilih satu peran seperti sebagai penasehat, fasilitator, instruktur, teman diskusi, penyemangat, pemberi hadiah atau guru pendidik d) Memberi peluang guru untuk "unjuk kerja". Tugas guru adalah membuat semua siswa belajar sampai berhasil. Tantangan profesionalnya justru terletak bagaimana mengubah siswa tak berminat menjadi bersemangat belajar (Dimyati,1994).

\section{a. Pengertian Hasil Belajar}

Hasil belajar pada hakekatnya adalah perubahan tingkah laku sebagai hasil dari proses belajar mengajar. Perubahan ini berupa pengetahuan, pemahaman, keterampilan dan sikap yang biasanya meliputi ranah kognitif, afektif dan psikomorik. Dimyati dan Mudjiono (2002: 174-176) serta Arikunto (2001:116-118) menjelaskan ranah-ranah tersebut sebagai berikut :

1. Ranah Kognitif (Cognitive domain)

2. Ranah Afektif (affective domain)

3. Ranah Psikomotorik (Psycomotor domain)

\section{METODE PENELITIAN}

Tempat yang digunakan adalah SMK Negeri 1 Airmadidi.

Penelitian dilakukan pada semester satu (ganjil) tahun pelajaran 2015/2016. Dalam penelitian yang dilakukan dua siklus dengan satu kompetensi dasar yaitu memahami konsep dan prosedur berbagai karya kerajinan tekstil dan limbahnya dengan pendekatan budaya setempat dan lainnya. 
Subyek penelitian ini adalah siswa kelas X Akuntansi SMK Negeri 1 Airmadidi dengan jumlah siswa 28 orang, yang terdiri dari 16 siswa putra dan 12 siswa putri.

Data penelitian yang dikumpulkan berupa prestasi belajar siswa dan keaktifan siswa kelas X Akuntansi SMK Negeri 1 Airmadidi serta faktor-faktor yang menyebabkan rendahnya prestasi siswa. Data dikumpulkan dalam berbagai sumber yang meliputi :

1. Guru pengamat, yanitu guru SMK Negeri 1 Airmadidi yang bertindak sebagai observer kegiatan : data yang diperoleh berupa buku nilai siswa, lembar observasi keaktifan siswa yang merekan aktifitas siswa ketika guru mengajar.

2. Siswa kelas X Akuntansi SMK Negeri 1 Airmadidi : data yang diperoleh berupa penilaian terhadap kondisi pembelajaran Prakarya dan Kewirausahaan di kelas dengan model inquiri dengan pendekatan kontekstual.

\section{PEMBAHASAN}

Dari data hasil observasi dapat dilihat bahwa, dalam kegiatan presentasi dan diskusi yang menggunakan metode inkuiri melalui pendekatan Kontekstual, rata-rata ketuntasan siswa dalam kelas pada siklus II adalah 94,70\% sedangkan pada siklus I yaitu $60,61 \%$. Hal ini menunjukkan bahwa siswa tuntas belajar berdasarkan nilai pada ranah psikomotor yaitu mempunyai daya serap $\geq 70$.

Pada pengamatan ranah psikomotor yaitu tentang keterampilan siswa dalam menjelaskan, yang diamati antara lain adalah kejelasan siswa dalam menyampaikan hasil pengamatan dan kepercayaan diri siswa dalam menjelaskan.

Pada aspek keterampilan menjelaskan dibagi menjadi dua kategori yaitu ketegori kejelasan dan kepercayaan diri. Kategori kejelasan siswa saat menjelaskan dalam presentasi pada siklus I, 1 siswa mendapatkan nilai pada rentang skor 3 sehingga jika dilihat dari rata-rata kelas yang berjumlah 28 siswa maka aspek kejelasan mempunyai nilai rata-rata 40,91\%, 10 siswa terletak pada rentang nilai antara 4 adalah 44,45\%, dan pada rentang nilai 5 diperoleh oleh 3 siswa adalah 13,64\%. Sedangkan pada siklus II mengalami peningkatan sebab tidak ada siswa yang nilainya pada rentang 3 nilai berada pada rentang 4 oleh 19 siswa yaitu dengan nilai rata-rata86,36\% dan pada rentang 5 diperoleh 3 siswa adalah $13,64 \%$. Adapun ketuntasan siswa yang mempunyai daya serap $\geq 70$ pada siklus II adalah 28 siswa (100\%) yang semula pada siklus I 14 siswa $(63,64 \%)$. Hal ini berdasarkan pada patokan untuk mata pelajaran Prakarya dan Kewirausahaan di SMK Negeri 1 Airmadidi, siswa dikatakan tuntas belajar jika mencapai nilai $\geq 70$. Dari hasil observasi dapat dikatakan bahwa kelas tersebut telah mencapai kriteria ketuntasan belajar yang ditetapkan yaitu $75 \%$.

Sedangkan jika dilihat aspek kepercayaan diri dalam menjelaskan, pada siklus I yang berada pada rentang $3(0-39 \%)$ ada 6 siswa sehingga mempunyai nilai rata-rata $27,27 \%$, sedangkan pada rentang $4(66-79 \%)$ oleh 12 siswa sehingga memperoleh nilai rata-rata 54,55\%. Pada rentang $5(80-100 \%)$ oleh 4 siswa sehingga memperoleh nilai ratarata $18,18 / \%$. Pada siklus II aspek kepercayaan diri, tidak ada siswa yang berada pada rentang $3(0-39 \%)$ tetapi pada rentang 4 (66-79\%) ada 19 siswa dengan nilai rata-rata $86,36 \%$ dan rentang $5(80-100 \%)$ ada 3 siswa dengan nilai rata-rata 13,64\%. Dari data tersebut dapat diketahui ketuntasan belajar siswa pada ranah psikomotor yang mencapai daya serap $\geq 70$ pada siklus II mengalami peningkatan dari $78,57 \%$ menjadi $100 \%$ pada siklus II. Hal ini berdasarkan pada patokan untuk mata pelajaran Prakarya dan Kewirausahaandi SMK Negeri 1 Airmadidi, siswa dikatakan tuntas belajar jika mencapai 
nilai $\geq 70$. Dari hasil observasi dapat dikatakan bahwa kelas tersebut telah mencapai kriteria ketuntasan belajar yang ditetapkan yaitu $75 \%$.

Pada aspek keterampilan mengajukan pertanyaan masih dibagi menjadi dua kategori yaitu kejelasan dan kerelevanan dalam mengajukan pertanyaan. Pada kategori kejelasan, pada siklus I diperoleh data bahwa pada rentang skor $3(0-39 \%)$ diperoleh oleh 11 siswa dengan nilai rata-rata 50\%, sedangkan pada rentang skor 4 (66-79\%) diperoleh 9 siswa yang memperoleh nilai rata-rata 40,91\% dan pada rentang skor $5(80-100 \%)$ diperoleh 2 siswa dengan nilai rata-rata 9,09\%. Sedangkan pada siklus II mengalami peningkatan, yaitu pada rentang skor $3(0-39 \%)$ hanya diperoleh 1 siswa dengan nilai rata-rata 4,55\% saja, pada rentang 4 (66-79\%) meningkat menjadi 13siswa dengan nilai rata-rata 59,09\% dan pada rentang 5 (80-100\%) diperoleh 8 siswa dengan nilai rata-rata $36,36 \%$. Berdasarkan hasil observasi dapat diketahui bahwa siswa yang tuntas belajar dengan mencapai nilai $\geq 70$, pada siklus I adalah 12 siswa $(54,55 \%)$ sedangkan siklus II adalah 20 siswa $(89,29 \%)$. Data tersebut menunjukkan bahwa kelas tersebut telah mencapai kriteria ketuntasan belajar yang ditetapkan yaitu $75 \%$ dan penerapan model pembelajaran inkuiri melalui pendekatan kontekstual ini tercapai. Menurut Nurhadi (2004: 73) bahwa inkuiri melibatkan komunikasi, siswa harus mengajukan pertanyaanpertanyaan yang berarti dan berhubungan. Pada kategori kerelevanan, pada siklus I pada rentang skor 3 (0-39\%) diperoleh oleh 9 siswa dengan nilai rata-rata 40,91\%, sedangkan pada siklus II yang berada pada rentang tersebut menjadi 3 siswa dengan nilai rata-rata $13,64 \%$. Hal ini menunjukkan bahwa pada siklus II mengalami peningkatan. Kemudian pada rentang skor 4 (66-79\%) diperoleh 10 siswa dengan nilai rata-rata 45,45\%, sedangkan pada siklus II diperoleh 16 siswa dengan nilai rata-rata 78,57\%. Dengan nilai tersebut menunjukkan bahwa terjadi peningkatan nilai rata-rata pada siklus II. Pada rentang skor 5 (80-100\%), di siklus I dan siklus II diperoleh 3 siswa dengan nilai ratarata $13,64 \%$.

Dari hasil observasi dapat dilihat bahwa siswa yang tuntas belajar pada siklus I adalah 13 siswa $(59,09 \%)$ sedangkan pada siklus II yaitu 19 siswa dengan rata-rata ketuntasan kelas $86,36 \%$ dapat dikatakan bahwa kelas tersebut belum mencapai kriteria ketuntasan belajar aspek kerelevanan menaggapi pertanyaan. Hal ini dimungkinkan karena siswa belum terbiasa dan kurang berani mengajukan pendapat atau ide-ide yang relevan dalam kegiatan diskusi-presentasi. Sebab selama ini kegiatan pembelajaran cenderung ceramah oleh guru pengajar. Hal ini sesuai dengan Nurhadi (2004: 27) bahwa program pembelajaran harus dikembangkan dengan keterampilan komunikasi spesifik mencakup mengembangkan komunikasi yang baik dan mengidentifikasi adanya miskonsepsi (salah konsep) yang mungkin berkembang.

Aspek keterampilan menanggapi dilihat dari dua kategori yaitu kejelasan menanggapi dan kerelevanan dalam menanggapi pertanyaan. Keterampilan menanggapi termasuk ranah psikomotorik tahap kesiapan yaitu mencakup kemampuan untuk menenpatkan dirinya dalam keadaan akan memulai suatu gerakan atau rangkaian gerakan (Winkel, 1996: 249). Untuk kejelasan menanggapi pada siklus I rentang skor 3 (0-39\%) diperoleh 12 siswa dengan nilai rata-rata 54,55\% sedangkan pada siklus II diperoleh 2 siswa dengan nilai rata-rata 9,09\%. Ini menunjukkan bahwa kemampuan siswa pada kategori kejelasan dalam menanggapi mengalami peningkatan pada siklus II. Pada rentang skor 4 (66-79\%) diperoleh 9 siswa dengan nilai rata-rata 40,91\%, sedangkan pada siklus II mengalami peningkatan yaitu diperoleh 16 siswa dengan nilai rata-rata 78,57\%. Pada rentang skor 5 (80-100\%), siklus I diperoleh 1 siswa dengan nilai rata-rata 4,55\%, sedangkan pada siklus II diperoleh 4 siswa dengan nilai rata-rata 10,27\%. Hal ini 
menunjukkan bahwa pada siklus II dengan kategori kejelasan dalam menanggapi pertanyaan mengalami peningkatan.

Dari hasil observasi dapat dilihat bahwa siswa yang tuntas belajar pada siklus I adalah 11 siswa (50\%) sedangkan pada siklus II yaitu 20 siswa dengan rata-rata ketuntasan kelas 89,29\%, dapat dikatakan bahwa kelas tersebut telah mencapai kriteria ketuntasan belajar yang ditetapkan yaitu $75 \%$. Aspek kerelevanan dalam menanggapi pertanyaan pada siklus I dengan rentang skor 3(0-39\%) diperoleh 8 siswa dengan nilai rata-rata $36,36 \%$, sedangkan pada siklus II sudah tidak ada siswa yang berada pada rentang skor 3 (0-39\%). Pada rentang skor 4(66-79\%), di siklus I diperoleh 12 siswa dengan nilai rata-rata 54,55\% sedangkan pada siklus II diperoleh 19 siswa dengan nilai rata-rata 86,36\%. Pada rentang skor $5(80-100 \%)$ ini pada siklus 2 siswa $(9,09 \%)$ yang masuk, sedangkan pada siklus II diperoleh 3 siswa dengan nilai rata-rata 13,64\%.

Adapun peningkatan nilai ranah psikomotor setiap aspek dapat dilihat pada Lampiran. Sedangkan peningkatan rata-rata nilai kelas pada ranah psikomotor dapat dilihat pada Tabel 4.7 berikut.

Tabel 4.3 Peningkatan Nilai Rata-rata Kelas Pada Ranah Psikomotor

\begin{tabular}{|l|l|l|l|}
\hline ASPEK RANAH PSIKOMOTOR & SIKLUS I & SIKLUS II \\
\hline \multirow{2}{*}{ KeterampilanMenjelaskan } & Kejelasan & $63,64 \%$ & $100 \%$ \\
\cline { 2 - 4 } & Kepercayaan Diri & $78,57 \%$ & $100 \%$ \\
\hline \multirow{2}{*}{$\begin{array}{l}\text { Keterampilan Mengajukan } \\
\text { Pertanyaan }\end{array}$} & Kejelasan & $54,55 \%$ & $89,29 \%$ \\
\cline { 2 - 4 } Keterampilan Menanggapi & Kerelevanan & $59,09 \%$ & $86,36 \%$ \\
\cline { 2 - 4 } & Kejelasan & $50 \%$ & $89,29 \%$ \\
\hline Nilai rata-rata kelas & Kerelevanan & $63,64 \%$ & $100 \%$ \\
\hline
\end{tabular}

Berdasarkan tabel tersebut di atas diketahui bahwa pada aspek keterampilan menjelaskan, rata-rata nilai kelas (kejelasan) yang diperoleh pada siklus I adalah 63,64\% termasuk kategori baik dan pada siklus II adalah $100 \%$ yang termasuk ke dalam kategori baik. Hal ini menunjukkan bahwa siswa sudah baik dalam keterampilan menjelaskan sehingga baik dari siklus I maupun siklus II tidak jauh berbeda peningkatannya $(36,36 \%)$. Hal ini sesuai dengan Sudjana (2004: 33) bahwa hasil belajar afektif dan psikomotor ada yang tampak pada saat proses belajar mengajar berlangsung dan ada pula yang baru tampak kemudian (setelah pengajaran diberikan) dalam praktik kehidupan dalam lingkungan keluarga, sekolah, dan masyarakat, itulah sebabnya hasil belajar afektif dan psikomotor sifatnya lebih luas, lebih sulit dipantau namun memiliki nilai yang sangat berarti bagi kehidupan siswa, sebab dapat secara langsung mempengaruhi perilaku siswa. Sedangkan nilai rata-rata kelas (kepercayaan diri) pada siklus I adalah 78,57\% denagn kategori baik dan siklus II yaitu $100 \%$ kategori baik. Hal ini juga menunjukkan bahwa kepercayaan diri siswa dalam menjelaskan sudah baik sehingga nilai rata-rata siswa antara siklus I dan siklus II mengalami peningkatan 27,27\%, yang tidak jauh berbeda.

Aspek keterampilan mengajukan pertanyaan, rata-rata nilai kelas (kejelasan) yang diperoleh adalah 54,55\% dengan kategori cukup dan siklus II 89,29\% dengan kategori Amat baik. Hal ini menunjukkan peningkatan aspek kejelasan pada keterampilan mengajukan pertanyaan yang semula pada siklus I pada kategori cukup menjadi kategori sangat baik. Untuk kerelevanan keterampilan mengajukan pertanyaan pada siklus I adalah 59,09\% kategori kurang dan siklus II yaitu 86,36\% dengan kategori baik. Hal ini 
menunjukkan bahwa siswa telah mampu dalam mengajukan pertanyaan yang relevan, yang semula pada siklus I termasuk ke dalam kategori kurang menjadi kategori baik pada siklus II.

Aspek keterampilan menanggapi yaitu (kejelasan) memperoleh 50\% kategori kurang pada siklus I dan siklus II 89,29\% kategori sangat baik, hal ini juga menunjukkan peningkatan siswa dalam kejelasan menanggapi pertanyaan. Sedangkan taraf kerelevanan pada siklus I 63,64\% kategori baik dan pada siklus II 100\% dengan kategori sangat baik. Hal ini menunjukkan bahwa siswa telah mampu menanggapi suatu masalah secara relevan. Untuk rata-rata nilai kelas pada ranah psikomotor juga mengalami peningkatan yaitu pada siklus I $60,61 \%$ kategori kurang menjadi $94,70 \%$ pada siklus II dengan kategori sangat baik. Data tersebut menunjukkan bahwa terjadi peningkatan nilai rata-rata ranah psikomotor. Hal ini sesuai dengan penelitian Ridwan (2008) bahwa pembelajaran kontekstual berpengaruh terhadap kemampuan psikomotor. Pada ranah psikomotor yang diukur melalui kegiatan presentasi dan diskusi ini menunjukkan keterampilan pada hierarkhis yang paling tinggi yaitu tingkat naturalisasi yaitu siswa melakukan gerakan tertentu secara spontan atau otomatis dalam mengajukan pertanyaan, menanggapi pertanyaan dan menjelaskan. Hal ini didukung oleh pernyataan Harrow (1972 dalam Suciati 2001) menyusun tujuan psikomotor secara hierarkhis dalam lima tingkat, mencangkup tingkat meniru sebagai yang paling sederhana dan naturalisasi sebagai yang paling kompleks.

Dari deskripsi mengenai hasil belajar siswa, secara umum dapat dikatakan bahwa ranah kognitif/ kognisi, ranah afektif/ afeksi, dan ranah konatif/ konasi terjadi peningkatan dari siklus I ke siklus II. Demikian juga hasil belajar ranah psikomotor meningkatkan dari siklus I ke siklus II. Temuan penting dari penelitian ini adalah penerapan model pembelajaran inkuiri melalui pendekatan kontekstual, meningkatkan motivasi dan hasil belajar terutama ranah afektif aspek kognisi/ kognitif (keyakinan siswa) dan ranah psikomotor aspek kerelevanan dalam menanggapi pertanyaan paling tinggi. Berdasarkan hasil penelitian ini disarankan kepada guru untuk menerapkan model pembelajaran inkuiri melalui pendekatan kontekstual pada kondisi siswa yang sama seperti pada penelitian.

\section{Kesimpulan}

1. Penerapan model pembelajaran inkuiri melalui pendekatan kontekstual (Contextual Teaching Learning) dapat meningkatkan motivasi belajar siswa Kelas X AkuntansiSMK Negeri 1 Airmadidi. Aspek motivasi meliputi perhatian, keterkaitan, keyakinan/ kepercayaan diri, dan kepuasan mengalami peningkatan antara 3,54\% hingga $11,41 \%$. Peningkatan tertinggi dari aspek keyakinan/ kepercayaan diri siswa yaitu sebesar $11,41 \%$.

2. Penerapan model pembelajaran inkuiri melalui pendekatan kontekstual (Contextual Teaching Learning) dapat meningkatkan hasil belajar siswa Kelas X AkuntansiSMK Negeri 1 Airmadidi yang meliputi ranah kognitif, afektif dan psikomotor. Siswa mengalami peningkatan pada ranah kognitif sebesar $10,27 \%$ yaitu dari $78,57 \%$ menjadi $89,29 \%$.

3. Hasil belajar ranah afektif mengalami peningkatan antara $11,82 \%$ hingga $15,45 \%$. Peningkatan yang paling tinggi yaitu pada aspek kognisi atau keyakinan siswa sebesar $15,45 \%$.

4. Sedangkan peningkatan ranah psikomotor antara $21,27 \%$ hingga $40,91 \%$. Peningkatan tertinggi diperoleh dari aspek kerelevanan dalam keterampilan 
menjelaskan yaitu sebesar 40,91\%. Nilai rata-rata kelas juga mengalami peningkatan sebesar 34,09\%. Pada ranah psikomotor yang diukur melalui kegiatan presentasi dan diskusi ini menunjukkan keterampilan pada hirarkis yang paling tinggi tingkat naturalisasi, siswa melakukan gerakan tertentu secara spontan atau otomatis dalam mengajukan pertanyaan, menanggapi pertanyaan dan menjelaskan.

\section{DAFTAR PUSTAKA}

Ella Yulaelawati. 2004. Kurikulum dan Pembelajaran. Jakarta: Pakar Raya E. Mulyasa. Eko P. Widiyoko2009. Evaluasi Program Pembelajaran. Jakarta: Pustaka Pelajar HB. Sutopo.2002. Metodologi Penelitian Kualitatif. Surakarta: UNS Press Hisyam Zaini. 2007. Strategi Pembelajaran Aktif. Yogyakarta: CTSD IAIN Sunan Kalijaga

Lexy J. Maleong. 2005. Metodologi Penelitian Kualitatif. Bandung: Rosda Karya Lee, V Miles \& Huberman. 1992. Data Kualitatif. Jakarta: UI Press

M. Nasir. 2004. Metode Penelitian. Jakarta: Gramedia

Nana Sudjana. 1991. Penilaian Hasil Proses Belajar Mengajar. Bandung: Rosda Karya Nasution. 1998. Berbagai Pendekatan dalam Proses Belajar dan Mengajar. Jakarta: PT. Bina Aksara

Supardi. 2009. Penelitian Tindakan Kelas. Jakarta: Gramedia 